AGRICULTURE AND BIOLOGY JOURNAL OF NORTH AMERICA

ISSN Print: 2151-7517, ISSN Online: 2151-7525, doi:10.5251/abjna.2011.2.7.1042.1047

(C) 2011, ScienceHu $\beta$, http://www.scihub.org/ABJNA

\title{
Antitrypanosomal Tetranotriterpenoids from Toona ciliata roots
} ${ }^{*}$ Mercy Githua ${ }^{1}$, Ahmed Hassanali ${ }^{2}$, Joseph Keriko ${ }^{1}$, Patrick Kareru ${ }^{1}$ Grace Murilla ${ }^{3}$, Mary Ndungu $^{1}$ and Gathu Nyagah ${ }^{1}$

\author{
${ }^{1}$ Department of Chemistry, Jomo Kenyatta University of Agriculture and Technology (JKUAT), \\ P.O Box 62000-00200 Nairobi, Kenya. \\ ${ }^{2}$ International Center of Insect Physiology and Ecology (ICIPE), P.O Box 30772, Nairobi, \\ Kenya. \\ ${ }^{3}$ Tyrpanosomiasis Research Center (TRC), P.O Box 362, Kikuyu, Kenya \\ *Corresponding author: Telephone: +254 0721350685 \\ Fax: +254 67-52164 \\ e-mail: githuamercy@yahoo.co.uk
}

\begin{abstract}
Organic extracts of the leaves of Toona ciliate $M$. Roem. yielded two antitrypanosomal terpenoids (1 and 2). These compounds were found to exhibit strong antitrypanosomal activities against Trypanosoma brucei rhodesiense with MIC value ranges of 7.18 and $31.25 \mu \mathrm{g} / \mathrm{ml}$. They were found to be more active than Cymerlarsan (a standard drug in the market), which had an MIC value of $187.5 \mu \mathrm{g} / \mathrm{ml}$ when tested against $T$. b. rhodesiense. Crude methanol extract and its chloroform fraction were found to be even more active with MIC values of 6.95 and $3.2 \mu \mathrm{g} / \mathrm{ml}$ respectively. The structures 1 and $\mathbf{2}$ were elucidated by spectroscopic methods including; NMR, MS, UV and IR.
\end{abstract}

Keywords: Toona ciliata, Trypanosoma brucei rhodesiense, antitrypanosomal activity, Cymerlarsan.

\section{INTRODUCTION}

Toona ciliata is a large subtropical deciduous tree with a spreading crown, commonly attaining a height of $20-30 \mathrm{~m}$ and a girth of $1.8-3 \mathrm{~m}$. It is of genus Toona and the family Meliaceae. Extracts of different parts of meliaceae family have been found to contain limonoids which are active against several diseases and their vectors that affect man and his animals (Mackinnon et al., 1997; Nagui, 1987; Spencer et al., 1997). The limonoids (tetranotriterpenoids) exhibit a wide range of anti-insect activity (Champagne et al., 1992; Bentley at al., 1995; Jayaprakasha et al., 1997; Simmonds et al., 2001) Various parts of Toona ciliata, but especially the bark, are used medicinally, e.g. as an astringent and tonic, to treat dysentery and to heal wounds. Different parts of this plant have been used for different purposes. In Southeast Asia the leaves are used as a vegetable and are sometimes chopped for fodder. The wood has a variety of uses such as for boat building, cabinet making, cigar boxes, matchboxes, decorative plywood and veneer, food containers, furniture, interior trim, joinery, musical instruments, ornamental work, paneling, boxes and crates, building materials, exterior uses, millwork and mouldings. The flowers contain a red colouring matter and also a sulphurcoloured dye and cotton and woollen fabric can be dyed a dull yellow by mere immersion in a boiling extract of $T$. ciliata flowers. Bark contains tannin, and it has also been used traditionally for twines and the manufacture of string bags. An aromatic oil can be extracted from the fruit. It is an important bee plant and one the species for honey production in Bangladesh.

Human African trypanosomiasis, (HAT), or sleeping sickness is caused by either of the two subspecies of Trypanosoma brucei, i.e T. brucei rhodesiense and $T$. brucei gambiense. Chemotherapy of HAT is hampered by drugs unavailability and toxicity (Pepin $\mathrm{J}$ and Milod F, 1994). Due to high cost involved in development and evaluation of new drug compounds, very few drugs have been developed over the past years. In addition, drug resistant parasites frequently appear. Therefore, there is need to explore the trypanocidal potential drugs from natural products especially those that are being used for the treatment of other protozoal and bacterial infections. 
We now report the structures of two limonoids ( 1 and 2 ) that were isolated from the roots of $T$. ciliata and their activities against $T$. $b$. rhodesiense.

\section{MATERIALS AND METHODS}

Plant materials: The roots of $T$.ciliata were collected from Nairobi Arboretum, central part of Kenya and were identified by a taxonomist of Botany department, University of Nairobi and voucher specimen No MG/3/2002 was deposited in the herbarium of that department.

Extraction and isolation of compounds from $T$. ciliate: Air dried and grounded powder of $T$. ciliata roots was extracted twice with methanol $(500 \mathrm{~g}$ to 1 liter) and the combined filtrates dried in vacuo to yield a reddish powder. The extract was partitioned between water $(100 \mathrm{ml})$ and chloroform $(250 \mathrm{ml} \times 3)$ and the resulting organic layer dried in vacuo. The methanol extract was subjected to reverse phase column chromatography. The column was packed with $\mathrm{C}_{18}$ and eluted with methanol/water gradient to obtain compounds 1 and 2 . Compound 1 was obtained as colorless needles eluted at $20 \%$ water whereas compound 2 was eluted at $40 \%$ water as white crystals. The purity of the isolates was confirmed by analytical HPLC and characterized by its IR, NMR, UV and MS spectral data.

Propagation of trypanosomes: T. $b$ rhodesiense (KETRI 3438) procyclic forms were obtained from Kenya Trypanosomiasis Research Institute (KETRI) trypanosomiasis bank and stored in liquid nitrogen. They were resuscitated and cultured until correct parastaemia for in vitro screening was obtained. The strain was isolated on $7^{\text {th }}$ July 1997 from a human patient and passaged through mice. The pre-patent period was six days while the pre-freezing period was twenty three days.

Antitrypanosomal bioassay: The procedure developed by Burri et al (1993) to determine the levels of melarsoprol in serum samples of animals after drug treatment was employed. The bioassay was carried out in 96 flat - bottomed wells plates with a lid (Corning Glass Works, Corning, New York) arranged in a matrix of 8 rows $\mathrm{A}-\mathrm{H}$ and 12 columns $1-12$. The tests were carried out in columns $11-2$ and rows $B-G$. The wells in columns 1 and 12 and rows $A$ and $H$ were not used due to high rate of evaporation. The stock solutions were prepared in sterilized distilled water $(1 \mathrm{mg} / \mathrm{ml})$ and diluted to appropriate concentrations. For every extract, three different concentrations were prepared, that is, 500 , 250 and $125 \mu \mathrm{g} / \mathrm{ml}$. Trypanosomes in logarithmic growth phase below $10^{6} / \mathrm{ml}$ one day after subpassaging were diluted to $2 \times 10^{3}$ cells $/ \mathrm{ml}$ in medium. $100 \mu \mathrm{l}$ of this trypanosome suspension was placed into each well. $100 \mu \mathrm{l}$ extract solution of each concentration was added to two adjacent wells of column 11. Serial dilutions were carried out by transferring $100 \mu$ from wells of column 11 to wells of column 10 by multi - channel pipettes, then from wells of column 10 to 9 , from 9 to 8 and so on up to wells of column 4 . For every test the highest concentration was in column 11 and in twofold dilution to the lowest in column 4 in 128 fold range, so that, for every extract, the highest concentration was $250 \mu \mathrm{g} / \mathrm{ml}$ and the lowest was $0.488 \mu \mathrm{g} / \mathrm{ml}$. Columns 3 and 2 were the controls, and no extract was added. Plates were incubated for 72 hours at $27^{\circ} \mathrm{C}$ in $5 \% \mathrm{CO}_{2}$.

Determination of minimum inhibition concentration: The test was read out under inverted microscope at 100 -fold magnification. In every row the highest dilution of either standard or samples with less than 5 motile trypanosomes of normal shape was determined. The concentration in this well was defined as the minimum inhibitory concentration (MIC), obtained using the equation:

$M I C^{*} D^{*} 2^{n}=C_{X}$, where,

$\mathrm{MIC}=$ Minimum Inhibitory Concentration

$\mathrm{D}=$ Dilution of extract by medium in wells of column 11 (maximum concentration)

$\mathrm{n}=$ Steps of dilution to the first well with no living trypanosomes

$\mathrm{C}_{\mathrm{x}}=$ Concentration of extract solution

${ }^{*}=$ Multiplication

\section{RESULTS AND DISCUSSION}

The HREIMS of compound 1 gave a molecular ion at $\mathrm{m} / \mathrm{z}(220)$ corresponding to $\mathrm{C}_{12} \mathrm{H}_{12} \mathrm{O}_{4}$. Mass spectral, peaks, were observed at $\mathrm{m} / \mathrm{z} 205\left[\mathrm{M}-\mathrm{CH}_{3}\right]^{+}, 192[\mathrm{M}$ $-\mathrm{CO}^{+}$and $177\left[\mathrm{M}-\mathrm{CO}, \mathrm{CH}_{3}\right]^{+}$indicating loss of $\mathrm{CH}_{3}, \mathrm{CO}$ and $-\mathrm{COCH}_{3}$, respectively. In the IR spectrum absorption bands at 1715, 1250 and 1637 $\mathrm{cm}^{-1}$ indicated presence of ketone, C-O and olefinic double bond, respectively. NMR spectral data was found to be similar to that reported for siderin, a coumerin synthesized from methyl-2-hydroxyl-4methoxy-6-methyl benzoate (Huettel et al., 2003). ${ }^{1} \mathrm{H}$ NMR showed presence of two methoxy $\left(\mathrm{OCH}_{3}\right)$ groups at $\delta_{H} 3.82(\mathrm{~s})$ and $3.92(\mathrm{~s})$ on carbons at $\delta_{\mathrm{C}}$ 55.5 and 55.9 , respectively. There was a tertiary methyl group at $\delta_{H} 2.60$ (s) on carbon at $\delta_{C} 23$. It had 
HMBC correlation with carbons at $\delta_{C} 107.8,115.6$, and 138.4. Carbon at $\delta_{C} 169.1$ had HMBC correlation with only one proton at $\delta_{H}$ 5.52. (s). This suggested that it could be a keto carbon and was placed at C- 2 .
Methoxy groups were on carbons at $\delta_{\mathrm{C}} 163.2$ (C-4) and 169.1 (C-7) (HMBC). The structure was proposed to be that of siderin (4,7-Dimethoxy-5methyl-2H-Chromen-2-one

Table 1: ${ }^{1} \mathrm{H},{ }^{13} \mathrm{C}$ NMR and $\mathrm{HMBC}$ spectral data for compound 1

\begin{tabular}{|l|l|l|l|}
\hline Proton/Carbon & $\delta \mathrm{H}(\mathrm{multi}, \mathrm{JHz})$ & $\delta_{\mathrm{c}}(\mathrm{ppm})$ & $\mathrm{HMBC}$ \\
\hline $1 \mathrm{a}$ & & 156.6 & \\
\hline 2 & & 169.1 & \\
\hline 3 & $5.52(\mathrm{~s})$ & 87.5 & $\mathrm{C}-4 \mathrm{a}, \mathrm{C}-2, \mathrm{C}-4$ \\
\hline 4 & & 163.2 & \\
\hline $4 \mathrm{a}$ & & 107.8 & \\
\hline 5 & & 138.4 & \\
\hline 6 & $6.60(\mathrm{~s})$ & 115.6 & $\mathrm{C}-8, \mathrm{C}-7, \mathrm{C}-4 \mathrm{a}, \mathrm{CH}_{3}$ \\
\hline 7 & & 161.9 & \\
\hline 8 & $6.65(\mathrm{~s})$ & 98.6 & $\mathrm{C}-4 \mathrm{a}, \mathrm{C}-1 \mathrm{a}, \mathrm{C}-6, \mathrm{C}-7$ \\
\hline $5 \mathrm{CH}_{3}$ & $2.60(\mathrm{~s})$ & 23.5 & $\mathrm{C}-4 a, \mathrm{C}-6, \mathrm{C}-5$ \\
\hline $4 \mathrm{OCH}_{3}$ & $3.92(\mathrm{~s})$ & 55.9 & $\mathrm{C}-4$ \\
\hline $7 \mathrm{OCH}_{3}$ & $3.82(\mathrm{~s})$ & 55.5 & $\mathrm{C}-7$ \\
\hline
\end{tabular}

The HREIMS of compound $\mathbf{2}$ has molecular formula of $\mathrm{C}_{26} \mathrm{H}_{30} \mathrm{O}_{5}(\mathrm{~m} / \mathrm{z} 422)$. On the mass spectra, peaks were observed at $\mathrm{m} / \mathrm{z} 407\left[\mathrm{M}-\mathrm{CH}_{3}\right]^{+}, 389[\mathrm{M}-$ $\mathrm{CH}_{3} \mathrm{H}_{2} \mathrm{O}^{+}$which indicated loss of methyl group and of hydroxyl group from the fragment $\mathrm{m} / \mathrm{z} 407$ respectively. The IR spectra indicated presence of ketone $\left(1715 \mathrm{~cm}^{-1}\right) \mathrm{C}-\mathrm{O}\left(1250 \mathrm{~cm}^{-1}\right)$, OH $(3500-$ $\left.3200 \mathrm{~cm}^{-1}\right)$ and olefinic double bond $\left(1637 \mathrm{~cm}^{-1}\right)$ The ${ }^{1} \mathrm{H}$ and ${ }^{13} \mathrm{C}$ NMR spectra data (Table 2) were similar to that of cedrelone (isolated from Walsura yunnarensis (Da- Gang et al., 2000)). ${ }^{1} \mathrm{H}$ NMR spectral data indicated presence of a $\beta$-substituted furan moiety at $\delta_{\mathrm{H}} 7.12(\mathrm{H}-21), 6.16(\mathrm{H}-22)$ and 7.35 $(\mathrm{H}-23))$. The signals at $\delta_{C} 127.3(\mathrm{~d}), 152.5$ (d) and 203.6 (s) in the ${ }^{13} \mathrm{C}$ NMR spectra corresponding to protons at $\delta_{\mathrm{H}} 6.09(1 \mathrm{H}, \mathrm{d}, \mathrm{J}=2.01 \mathrm{~Hz})$ and $6.90(1 \mathrm{H}$, $\mathrm{d}, \mathrm{J}=0.99 \mathrm{~Hz}$ ) are typical signals of $\alpha, \beta$-unsaturated ketone moiety in the $A$ ring. Examination of COSY revealed that methine protons at $\delta_{H} 6.09$ coupled with methine protons at $\delta_{H} 6.90$ which allowed the assignment of $\delta_{\mathrm{H}} 6.09$ to $\mathrm{C}-2$ and 6.90 to $\mathrm{C}-1$. From HMBC correlations cross peaks between proton at $\delta_{H}$ $6.90(\mathrm{H}-1)$ and methyl protons at $\delta_{\mathrm{H}} 1.50$ and 1.55 with carbon at $\delta_{C} 203.6$ permits the assignment of keto carbon at C-3. Absence of cross peaks between protons at C-5 and C- 6 indicated that $\mathrm{C}-5$ is a quartenary carbon, confirming a double bond between the two. Cross peaks between carbon at $\delta_{C} 133.9$ and methyl protons at $\delta_{H} 1.50,1.55$ and 6.90 confirmed that $\mathrm{C}-5$ was at $\delta_{C}$ 133.9. A quartenary carbon observed at $\delta_{C} 197.9$ suggested the carbon was a ketone. The assignment of relative stereochemistry was based on the NOESY experiments. The $\mathrm{H}-9 \alpha$ resonance showed a NOESY correlation with $\mathrm{H}-4, \mathrm{H}-11, \mathrm{H}-12$, and $\mathrm{H}-13$ confirming the $\alpha$ orientation of $\mathrm{H}$ 's on $\mathrm{C}-4, \mathrm{H}-11, \mathrm{H}-12$, and $\mathrm{H}-13$. $3 \mathrm{H}-30 \beta$ resonance showed a NOESY correlation with $\mathrm{H}-4 \beta$ and $3 \mathrm{H}-19 \beta$ whereas $\mathrm{H}-17 \beta$ resonance showed a NOESY correlation with $\mathrm{H}-11$ and $\mathrm{H}-12$ confirming the $\beta$-orientation of $\mathrm{H}$ 's on $\mathrm{C}-4, \mathrm{C}-11$ and $\mathrm{C}-12$ (Figure 2) 
Table 2: ${ }^{1} \mathrm{H},{ }^{13} \mathrm{C}$ NMR and HMBC spectral data for compound 2

\begin{tabular}{|c|c|c|c|}
\hline Proton/Carbon & $\delta_{\mathrm{H}} \mathrm{ppm}$, multi, JHz & $\delta_{\mathrm{C}}(\mathrm{ppm})$ & HMBC \\
\hline 1 & $6.90(d, 0.9)$ & $152.5(d)$ & $\mathrm{C}-10, \mathrm{C}-5, \mathrm{C}-3$ \\
\hline 2 & $6.09(d, 2.0)$ & $127.3(\mathrm{~d}$ & C-4, C-3, C-10 \\
\hline 3 & & $203.6(s)$ & \\
\hline 4 & & $48.5(\mathrm{~s})$ & \\
\hline 5 & & $133.9(\mathrm{~s})$ & \\
\hline 6 & & $141.1(\mathrm{~s})$ & \\
\hline 7 & & $197.9(\mathrm{~s})$ & \\
\hline 8 & & $46.7(\mathrm{~s})$ & \\
\hline 9 & $2.65(\mathrm{~m}, 2.0)$ & $43.1(d)$ & C-5, C-7, C-1, C19,C-10, C-11, C-12, C-8 \\
\hline 10 & & $40.3(\mathrm{~s})$ & \\
\hline 11 & $1.83(\mathrm{~m})$ & $19.4(\mathrm{t})$ & C-!2, C-9, C-13, C-8,C-10 \\
\hline 11 & $1.85(\mathrm{~m}, 2.8)$ & & \\
\hline 12 & $1.64(\mathrm{~m}, 1,2)$ & $35.2(\mathrm{t})$ & C-11, C-18, C-13, C-14 \\
\hline 12 & $2.06(\mathrm{~m}, 0.9)$ & & \\
\hline 13 & & $41.9(\mathrm{~s})$ & \\
\hline 14 & & $69.8(s)$ & \\
\hline 15 & $3.74(\mathrm{~s})$ & $55.1(d)$ & \\
\hline 16 & $1.94(\mathrm{~m}, 2.8)$ & $31.9(\mathrm{t})$ & C-18, C-12 \\
\hline 16 & $2.20(\mathrm{~m}, 1.1)$ & & \\
\hline 17 & $2.73(\mathrm{~m}, 2.0)$ & $41.7(\mathrm{t})$ & C-18, C-16, C-12, C-13, C-22, C-20, C-21 \\
\hline 18 & $0.73(\mathrm{~s})$ & $23.8(q)$ & $\mathrm{C}-12, \mathrm{C}-13, \mathrm{C}-14$ \\
\hline 19 & $1.27(\mathrm{~s})$ & $23.9(q)$ & C-10, C-9, C-5, C-1 \\
\hline 20 & & $123.2(\mathrm{~s})$ & \\
\hline 21 & $7.12(\mathrm{~s})$ & $139.3(d)$ & $\mathrm{C}-17, \mathrm{C}-20, \mathrm{C}-22$ \\
\hline 22 & $6.16(\mathrm{~s})$ & $110.6(d)$ & C-20, C-21, C-17 \\
\hline 23 & $7.35(\mathrm{~s})$ & $142.9(\mathrm{~d})$ & $\mathrm{C}-22, \mathrm{C}-20$ \\
\hline 28 & $1.55(\mathrm{~s})$ & $26.7(q)$ & $\mathrm{C}-4, \mathrm{C}-5, \mathrm{C}-3, \mathrm{C} 28$ \\
\hline 29 & $1.50(\mathrm{~s})$ & $21.2(\mathrm{q})$ & $\mathrm{C}-4, \mathrm{C}-5, \mathrm{C}-3, \mathrm{C}-28$ \\
\hline 30 & $1.07(\mathrm{~s})$ & $20.2(q)$ & C-8, C-14, C-9, C-7 \\
\hline $6 \mathrm{OH}$ & $6.46(\mathrm{~s})$ & & \\
\hline
\end{tabular}


<smiles>COc1cc(C)c2c(OC)cc(=O)oc2c1</smiles>

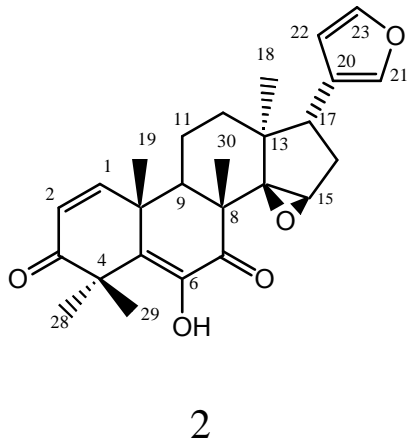

Fig 1: Chemical structures of compounds 1 and 2

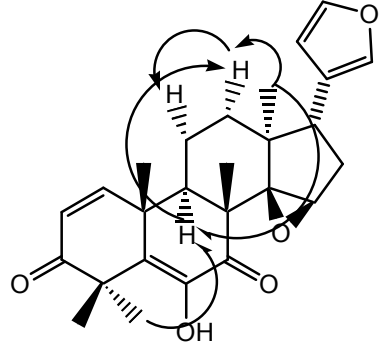

Lower side

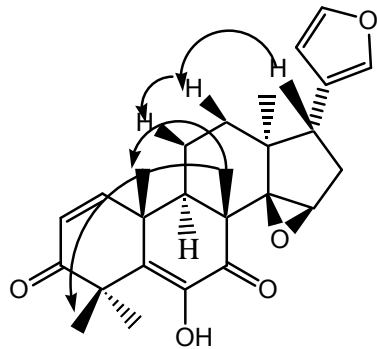

Top side

Fig 2: NOESY correlation of compound 2

\section{Antitrypanosomal activity}

Table 3: Antitrypanosomal in vitro activity of $T$. ciliata roots extracts against $T$. $b$. rhodesiense procyclic form (KETRI 3438)

\begin{tabular}{|l|l|}
\hline Sample & Activity $(\mathrm{MIC}) \mu \mathrm{g} / \mathrm{ml}$ \\
\hline Methanol extract & $6.95 \pm 0$ \\
\hline Chloroform extract & $3.2 \pm 0$ \\
\hline Compound 1 & $31.25 \pm 0$ \\
\hline Compound 2 & $7.85 \pm 0$ \\
\hline Cymerlarsan & $187.5 \pm 0$ \\
\hline
\end{tabular}

Crude methanolic and chloroform extracts of $T$..ciliata exhibited significant antitrypanosomal in vitro activities against $T$. b. rhodesiense procyclic forms (KETRI 3438) whose MIC values are $6.95 \pm 0$ and $43.2 \pm 0 \mu \mathrm{g} / \mathrm{ml}$, respectively. The two isolated compounds had lower activities suggesting that there are other antitrypanosomal compounds present or possible synergistic blend effects. Chloroform extracts were more potent than the methanol extracts, indicating that the active compounds are of medium polarity.

Based on their spectroscopic data and comparison with published data, the structures of the compounds were readily elucidated and were found to be siderin (4,7-Dimethoxy-5-methyl-2H-Chromen-2-one) (compound 1) and cedrelone (compound 2). Compound $\mathbf{2}$ which has the basic structure of nimbolide and an epoxy group between $\mathrm{C}_{14}$ and $\mathrm{C}_{15}$ had higher activity than compounds 1 although lower than that of chloroform and methanol extracts. This suggested that $T$. ciliata could be a source of new effective antitrypanocidal drugs with novel modes of action.

\section{ACKNOWLEDGMENTS}

We are grateful to Mr. S. G. Mathenge and Mr. Mutiso both of University of Nairobi, Botany Department and Mr. D. Gitau for their assistance in collection and identification of plant materials. We acknowledge Dr. Tony Hopper of IACR- Rothamsted for performing the Nuclear Magnetic Resonance (NMR) experiments and his valuable advice and 
guidance on the interpretation of the data. The staff of tissue culture section of Tyrpanosomiasis Research Center (TRC) are acknowledged for their assistance in bioassays.

\section{REFERENCES}

Baltz, T.; Baltz, D.; Giroud, C.; Crokett, J. (1985. Cultivation in semi defined medium of animal infective forms of Trypanosoma brucei, T. equiperdum, t. evansi, $T$. rhodesciense and T. gambiense. EMBO journal 4, 1273-1277

Bentley, M. D.; Adul, G. O; Alfred, A, R.; Huang, F, Y.; Gelbaum, L.; Hassanali, A. (1995). An insect antifeedant from Turraea nilotica, J. Nat. Prod. 58, 748-750.

Bray, A. D.; Warhust, D.; Connolly, J. D.; Neil, M. J. O.; Phillipson, J. D. (1990). Plants as sources of Antimalarial Drugs. Part 7. Activity of some species of Meliaceae plants and their constituent Limonoids, Phytotherapy Research 4, 29-35.

Burri, C.; Baltz, T.; Giroud, C.; Doua, F.; Welker, H. A.; Brun, R. (1993). Pharmacokinetic properties of trypanocidal drug melarsoprol. Chemother. 39, 225234.

Champagne, D. E.; Koul, O.; Isman, M. B.; Scudder, M. E.; Towers, G. H. N. (1992). Biological activity of limonoids from the Rutates. Phytochemistry 31, 377-394
Da-Gang, W.; Xiao-Dong, L.; Shao-Hua, W.; Yun-Bao, M. (2000). Tetranotriterpenoids from Wausura yunnanensis. J. Nat. Prod. 63, 947-951.

Jayaprakasha, G, K.; Singh, R, P.; Pereira, j; Sakariah, K, K (1997) ( Limonoids from Citrus reticulata and their moult inhibiting activity in mosquito Culex quinquefazciatus larvae. Phytochemistry, 44, 843 - 846

Mackinon, S.; Durst, T.; Arnason, J. T. (1997). Antimalaria activity of tropical Meliaceae extracts and Gedunin derivatives. J. Nat. Prod. 60, 336-341

Nagui, S. N. H. (1987). [Eds.] In Natural pesticides from the Neem tree and other Tropical plants. Proceedings of the $3^{\text {rd }}$ Neem conference (Nairobi, 1996) GTZ, Eschborn Germany, p315.

Okpanyi, S. N. and Ezeukwu, G. C., (1981). Antiinflammatory and antipyretic activities of Azadirachta indica. Planta. Med., 41: 34

Simmonds, M.S.J: Stevenson, P. C porter, E,A; Veitch, N. C.( 1997) Insect antifeedant activity of three new tetranonrtriterpenoids from trichilia palida. J Nat.Prod 2001,64, 1117- 1120.

Spencer, C. F.; Koniusg, F. R.; Rogers, E. F.; shavel, T. J.; Easton, N. R.; Kaezka, E. A.; Matanya, C.; Seelar, A. D. (1997). Lioydia 10, 145.

Sudaratana, R .; Yodhathai, T .; Chavi, Y .; Yongyuth, Y. (1985). Nimbolide, a constituent of Azadirachta indica inhibits Plasmodium Falciparum in culture. Southeast Asian J.Trop. Med. Pub. Hlth., 161 